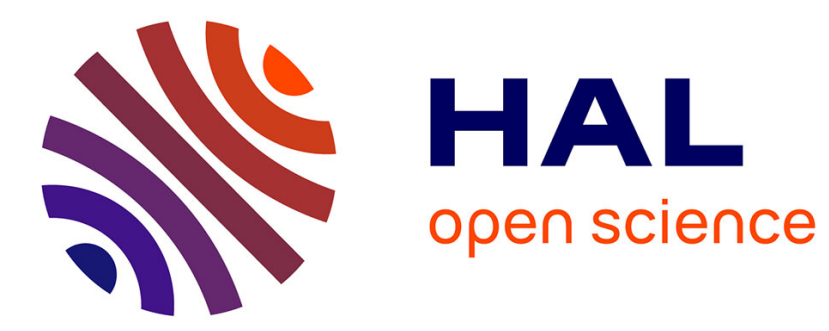

\title{
THE EFFECT OF MANGANESE ON INTERGRANULAR FRACTURE IN LOW ALLOY STEELS
}

K. Tatsumi, N. Okumura, M. Yamamoto

\section{- To cite this version:}

K. Tatsumi, N. Okumura, M. Yamamoto. THE EFFECT OF MANGANESE ON INTERGRANULAR FRACTURE IN LOW ALLOY STEELS. Journal de Physique Colloques, 1988, 49 (C5), pp.C5-699C5-704. 10.1051/jphyscol:1988592 . jpa-00228089

\section{HAL Id: jpa-00228089 https://hal.science/jpa-00228089}

Submitted on 1 Jan 1988

HAL is a multi-disciplinary open access archive for the deposit and dissemination of scientific research documents, whether they are published or not. The documents may come from teaching and research institutions in France or abroad, or from public or private research centers.
L'archive ouverte pluridisciplinaire HAL, est destinée au dépôt et à la diffusion de documents scientifiques de niveau recherche, publiés ou non, émanant des établissements d'enseignement et de recherche français ou étrangers, des laboratoires publics ou privés. 
THE EFFECT OF MANGANESE ON INTERGRANULAR FRACTURE IN LOW ALLOY STEELS

\author{
K. TATSUMT, N. OKUMURA and M. YAMAMOTO \\ R\&D Laboratories-I, Nippon steel Corporation, 1618 Ida, Nakaharaku, \\ Kawasaki 211, Japan
}

\begin{abstract}
-Abstract- The grain boundary embrittlement of low alloy steels was studied, attention being paid to the effect of manganese concentration. The prior austenite grain boundary of tempered martensitic samples containing $0.5,1.0,1.5 \mathrm{wt} \% \mathrm{Mn}$ were analyzed by AES. (1)Increasing bulk manganese content was found to cause a small increase in the amount of segregated phosphorus and a decrease in the amount of segregated carbon. (2) Measurements of internal friction (Snoek peak) showed that the addition of manganese lowered the concentration of dissolved carbon. Based on these facts, the embrittling effect of manganese can be explained by the decrease of the concentration of segregated carbon which strengthens grain boundaries.
\end{abstract}

\title{
I-Introduction
}

Phosphorus is the most common embrittling element in commercial steels. It has long been recognized from experimental studies that the embrittlement caused by phosphorus depends on the alloying elements present in low alloy steels. The detrimental effect of alloying elements like $\mathrm{Mn}, \mathrm{Cr}$, etc. on the temper embrittlement of low alloy steels is well known but the role of alloying elements especially manganese has not yet been satisfactorily explained. The effect is explained in terms of cosegregation of manganese with phosphorus $/ 1,2 /$ and/or increased embrittling potency of phosphorus caused by manganese $/ 1,3 /$. On the other hand it has been shown that the phosphorus concentration at grain boundary is not affected by addition of manganese/3,4,5/.

The aim of the present investigation is to study the segregation behavior of $P$, $\mathrm{Mn}$ and $\mathrm{C}$ in low alloy steels and to clarify the effect of bulk Mn content on the intergranular fracture.

\section{II-EXPERIMENTAL}

The compositions of the alloys used in this study are given in Table 1. These composition ranges are typical of oil country tubular goods except for the phosphorus content. The manganese concentration varied from 0.5 to 1.5 wt.\% and the phosphorus concentration varied from 0.05 to $0.1 \mathrm{wt} \%$

The steels were vacuum melted, cast, homogenized at $1100^{\circ} \mathrm{C}$ and hot rolled to plates of $15 \mathrm{~mm}$ in thickness.

All samples were austenitized at $950^{\circ} \mathrm{C}$ for 2 hours, water quenched, aged at 
various temperature for different time periods and water quenched. The aging conditions were as follows: $700^{\circ} \mathrm{C}-0.2 \mathrm{~h}, 2 \mathrm{~h}, 650^{\circ} \mathrm{C}-0.2 \mathrm{~h}, 2 \mathrm{~h}, 20 \mathrm{~h}, 600^{\circ} \mathrm{C}-$ $0.2 \mathrm{~h}, 2 \mathrm{~h}, 20 \mathrm{~h}, 200 \mathrm{~h}, 550^{\circ} \mathrm{C}-0.2 \mathrm{~h}, 2 \mathrm{~h}, 20 \mathrm{~h}, 200 \mathrm{~h}$. The areal ratio of the intergranular fracture of the specimens was determined by taking SEM fractographs.

Table 1 Chemical Compositions (wt.\%)

\begin{tabular}{|c|c|c|c|c|c|c|c|c|c|c|c|}
\hline & C & $\mathrm{Si}$ & $\mathrm{Mn}$ & $P$ & $\mathrm{~S}$ & $\mathrm{Cr}$ & $\mathrm{Nb}$ & Al & $T i$ & B & $\mathrm{N}$ \\
\hline $\begin{array}{l}\mathrm{A} \\
\mathrm{B}\end{array}$ & $\begin{array}{l}0.23 \\
0.23\end{array}$ & $\begin{array}{l}0.048 \\
0.047\end{array}$ & $\begin{array}{l}0.52 \\
1.03\end{array}$ & $\begin{array}{l}0.056 \\
0.057\end{array}$ & 0.0007 & 0.47 & 0.044 & $\begin{array}{l}0.022 \\
0.023\end{array}$ & $\begin{array}{l}0.014 \\
0.013\end{array}$ & $\begin{array}{l}0.0009 \\
0.0010\end{array}$ & 0.0014 \\
\hline C & 0.22 & 0.048 & 1.57 & 0.055 & 0.0011 & 0.47 & 0.042 & 0.023 & 0.011 & 0.0010 & 0.0014 \\
\hline D & 0.20 & 0.055 & 0.51 & 0.113 & 0.0007 & 0.40 & 0.041 & 0.028 & 0.015 & 0.0010 & 0.0013 \\
\hline $\mathrm{E}$ & 0.19 & 0.054 & 0.96 & 0.111 & 0.0008 & 0.39 & 0.040 & 0.026 & 0.013 & 0.0010 & 0.0013 \\
\hline $\mathrm{F}$ & 0.19 & 0.053 & 1.49 & 0.109 & 0.0010 & 0.39 & 0.038 & 0.025 & 0.013 & 0.0009 & 0.0013 \\
\hline G & 0.20 & 0.050 & 0.50 & 0.057 & 0.0006 & 0.42 & 0.047 & 0.024 & 0.018 & 0.0010 & 0.0011 \\
\hline $\mathrm{H}$ & 0.19 & 0.050 & 1.02 & 0.058 & 0.0008 & 0.42 & 0.048 & 0.022 & 0.018 & 0.0010 & 0.0011 \\
\hline$I$ & 0.19 & 0.050 & 1.47 & 0.060 & 0.0009 & 0.42 & 0.047 & 0.021 & 0.018 & 0.0010 & 0.0011 \\
\hline
\end{tabular}

Auger electron spectroscopy (AESPHI600) was used to study grain boundary segregation. The specimens placed in the vacuum chamber $\left(1 \times 10^{-8} \mathrm{~Pa}\right)$ were cooled down to $-100^{\circ} \mathrm{C}$ and then fractured by a hammer. They were examined in the spectrometer by scanning electron microscopy to determine the location of grain boundary facets. The composition of individual facets was then determined by AES. The operating conditions of the AES measurement were as follows: Primary beam energy $10 \mathrm{kV}$, Beam current 0.1-0.5 $\mu \mathrm{A}$, Beam diameter $0.1-2 \mu \mathrm{m}$, Sweep conditions $0.5 \mathrm{eV} / \mathrm{step} 100 \mathrm{msec} / \mathrm{step}$.

When information on the surface composition profile was needed, ion sputtering was performed with purified $\mathrm{Ar}^{+}$gas under the following conditions: Ar pressure $1 \times 10^{-2} \mathrm{~Pa}$, Accelerating voltage $3 \mathrm{keV}, \mathrm{Filament}$ current $25 \mathrm{~mA}$. The grain boundary concentration was calculated from Auger peak heights using the standard elemental sensitivity factors published in the Physical Electronics Handbook $/ 6 /$. The Auger peaks used were as follows: P $120 \mathrm{eV}, \mathrm{C} 272 \mathrm{eV}, \mathrm{Mn} 542 \mathrm{eV}$, $\mathrm{Fe} 703 \mathrm{eV}$.

To study the effect of $\mathrm{Mn}$ on the dissolved carbon concentration, internal friction of the specimens (aged for $200 \mathrm{~h}$ at $600^{\circ} \mathrm{C}$ ) was measured over a temperature range from $-70^{\circ} \mathrm{C}$ to $130^{\circ} \mathrm{C}$ by an inverted torsion pendulum. The heating rate was $2 \mathrm{~K} / \mathrm{min}$ and frequency for measurement was ca.0.5Hz.

\section{III-Results}

The variation of hardness in the specimens containing $0.5,1.0$ and 1.5 wt\% $\mathrm{Mn}$ in different aging conditions are shown in Fig.1. The digits by the symbols in the figure indicate the
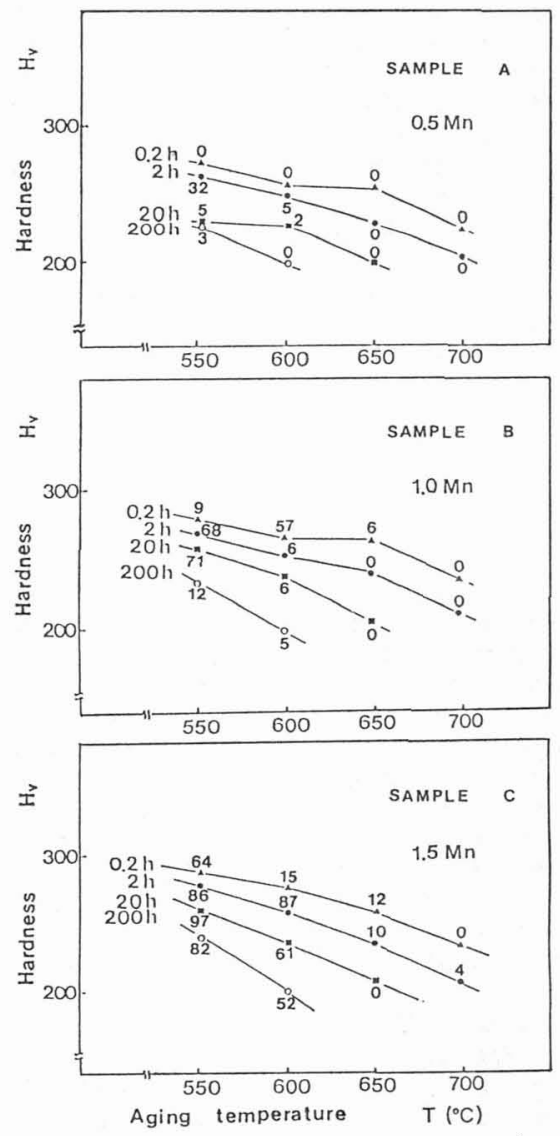

Fig.1 Relation between hardness and percentage of intergranular fracture (digits by the symbols in the figure) in low alloy steels containing 0.5 , 1.0 and 1.5 wt\% $\mathrm{Mn}$ for various heat treatments 


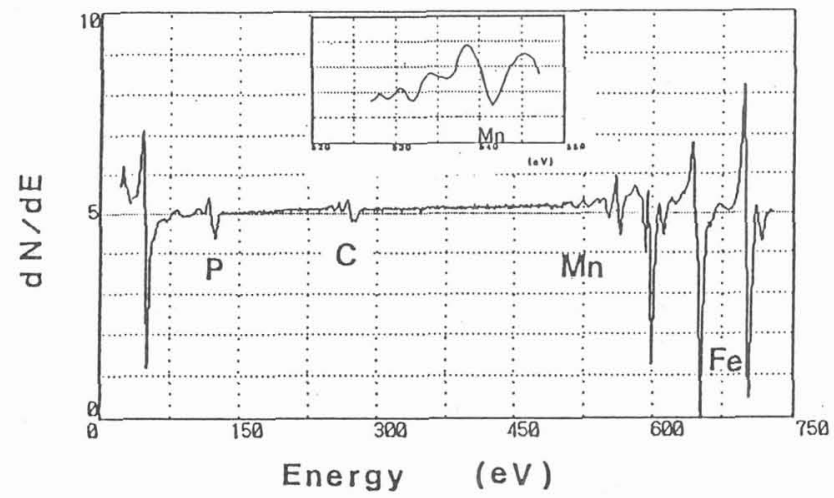

Fig.2 Auger spectrum obtained from the grain boundary facets revealed by fracture, showing that the elements of $\mathrm{P}, \mathrm{C}, \mathrm{Mn}$ and Fe are detected.

(sample:F aged for 2 hours at $600^{\circ} \mathrm{C}$ )

percentage of intergranular fracture of the specimens fractured in a standard impact test at $-100^{\circ} \mathrm{C}$. The results show that manganese had no significant effect on hardness in all aging conditions, but caused a large increase in the amount of intergranular fracture.

A typical Auger spectrum taken on the intergranular fracture surface is shown in Fig.2. The spectrum shows Auger peaks of $\mathrm{P}, \mathrm{C}, \mathrm{Mn}$ and $\mathrm{Fe}$. Auger sputtering profiles were also taken to examine whether $P, C$ and $M n$ are segregated locally at grain boundaries or tied up in a three dimensional second phase. As shown in Fig. 3 after removal of a few atom layers, phosphorus could not be detected while the amount of carbon remains to be a certain value even after 2 minutes sputtering. It appears, therefore, that carbon is tied up in the grain boundary precipitates $\left(\mathrm{Fe}_{3} \mathrm{C}\right)$ apart from grain boundary segregation. Manganese appears to have also segregated to the grain boundaries as shown in Fig.4a. Although the Mn peaks overlap the $\mathrm{Fe}$ peaks, Mn $542 \mathrm{eV}$ peaks could be clearly detected by multiplying the sweeps of Auger spectrum (number of sweeps: 6), resulting in suppressing the background noise in the spectrum. The disappearance of $\mathrm{Mn} 542$ peaks in the spectrum obtained from the grain boundary facet sputtered for 20

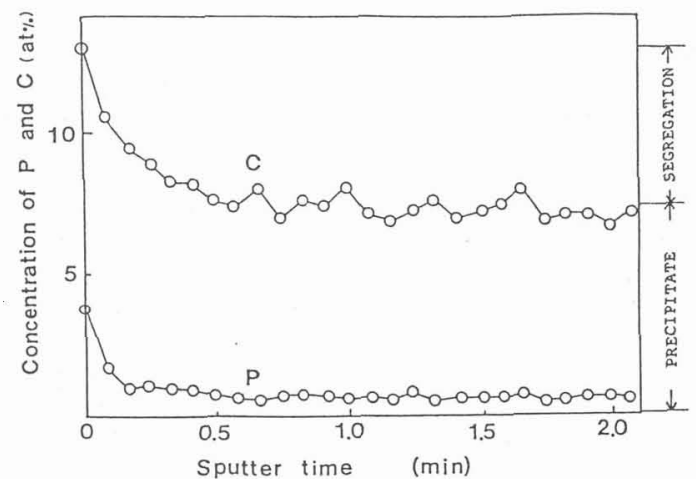

Fig.3 Concentration profile of phosphorous and carbon in vicinity of grain boundary of sample $C$ (Sputtering rate is estimated to be ca. $60 \AA / \mathrm{min}$, assuming uniform sputtering rate equivalent to that of pure iron target.)
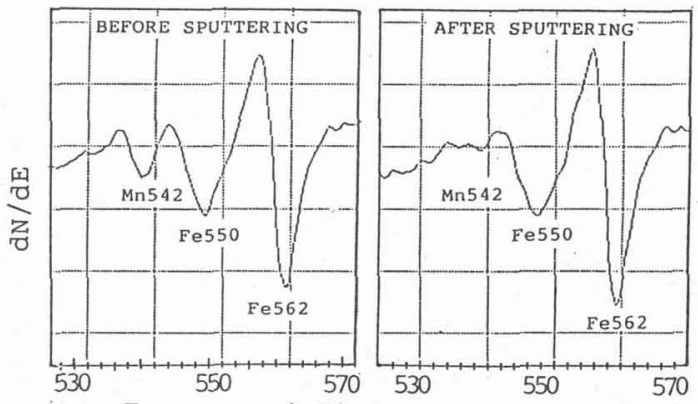
(4a) Energy
(eV)
(4b) Energy
(eV)

Fig.4 Mn $542 \mathrm{eV}$ Auger peaks obtained from intergranular fracture surface of sample $\mathrm{C}$ aged for 2 hours at $600^{\circ} \mathrm{C}$, before and after sputtering 
seconds shows that manganese is indeed enriched locally on the grain boundaries (Fig. 4b) and that the observed Mn peak in the spectrum in Fig 4 a does not mean the manganese tied up in the grain boundary precipitates.

Quantitative analysis of grain boundary segregation was performed for at least eighteen grain boundary facets. Fig.5 shows the effect of bulk concentration of manganese on grain boundary concentration of phosphorus and manganese in the specimen aged for 2 hours at $600^{\circ} \mathrm{C}$. Each plot in the figure corresponds to a measured value on each grain facet. The amounts of segregated $P$ and $M n$ vary from facet to facet to a substantial degree. The variation can be explained by the difference in the grain boundary structure $/ 7,8 /$.

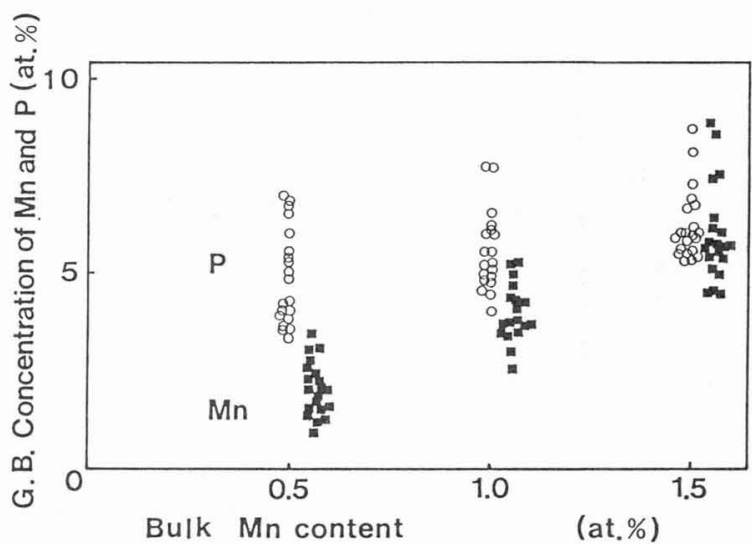

Fig.5 Effect of bulk concentration of $\mathrm{Mn}$ on grain boundary cocentration of $P$ and $\mathrm{Mn}$ in martensitic low alloy steels aged for 2 hours at $600^{\circ} \mathrm{C}$ (sample:D, E and F)

The maximum level of the phosphorus segregation is slightly increased by increasing bulk manganese content. The amount of segregated manganese obviously increases with increasing bulk manganese content. The role of the segregation of manganese in intergranular fracture behavior is discussed later.

It has been realized that the segregated carbon exerts a profound strengthening influence in alpha iron/9/. Although the beneficial effect of segregated carbon would be expected also in the fracture of prior austenite grain boundaries, the behavior of the carbon segregation to the grain boundaries has been little investigated. in low alloy steels. We tried to estimate the grain boundary segregation of carbon in low alloy steels by means of AES analysis, assuming that the decrease of the carbon peak observed by sputtering of a few layers on the grain boundary facet corresponds to the amount of segregated carbon (see Fig.3): \% of segregated carbon $=\%$ of total carbon (before sputtering) - \% of precipitates carbon (after sputtering).

Fig.6 shows the concentration of carbon segregated to the grain boundary of the specimen aged for 2 hours at $600^{\circ} \mathrm{C}$ as a function of bulk manganese content. From the results it can be concluded that the amount of segregated carbon tends to decrease with increasing the manganese content, in contrast to the behavior of the phosphorus segregation.

Assuming the carbon segregation is in equilibrium with the dissolved carbon, the concentration of dissolved carbon should decrease as the bulk content of manganese increases. To investigate the effect of manganese on the concentration of dissolved carbon we measured the internal friction of the tempered martensitic specimen aged for 200 hours at $600^{\circ} \mathrm{C}$, containing $0.5,1.0$ and 1.5 wt\% Mn. Fig.7 demonstrates clearly that addition of manganese causes a large decrease in the Snoek peak height which is considered as proportional to the concentration of dissolved carbon.

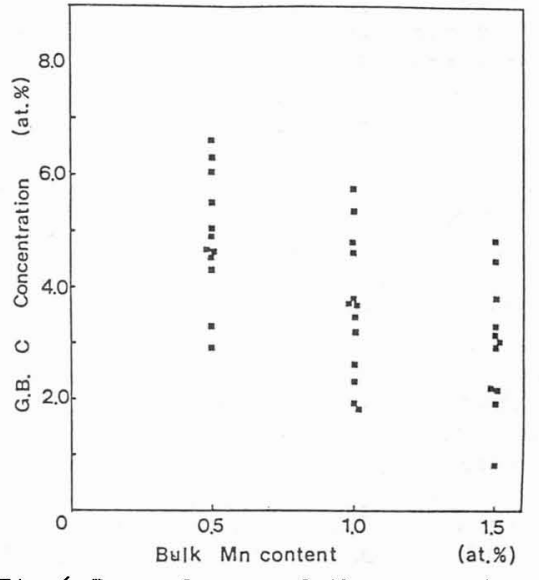

Fig.6 Dependence of the concentration of segregated $\mathrm{C}$ on bulk $\mathrm{Mn}$ concentration (samle D, E and $F$ aged for 2 hours at $600^{\circ} \mathrm{C}$ ) 


\section{IV-DISCUSSION}

Phosphorus segregation

Clayton and Knott/1/reported that the addition of $0.6 \mathrm{wt} \% \mathrm{Mn}$ to $\mathrm{Ni}-\mathrm{Cr}$ steel increases the degree of phosphorus segregation. On the other hand Briant/4/ reported that manganese has no effect on phosphorus segregation in low alloy steels. The reason why the literature is far from conclusive on the effect of manganese on the phosphorus segregation may be due to the significant variation in grain boundary segregation among different grain boundary facets. The present data shown in Fig. 4 is in good agreement with the recent results by Yu-quing and McMahon/12/. They also analyzed the individual grain boundary facet in martensitic steels by AES, taking account of the variation and found that manganese caused a small increase in the phosphorus concentration on the grain boundary. The increase of phosphorus segregation in manganese containing steels was explained by the attractive interaction between manganese and phosphorus $/ 1,12 /$. However recent studies by Lee et $a 1$. $/ 3 /$ and the present authors (Fig.8) showed that no enrichment of phosphorus was observed in carbon free $\mathrm{Fe}-\mathrm{P}$ $\mathrm{Mn}$ alloys, i.e. manganese alone did not affect the grain boundary concentration of phosphorus. An alternative possible explanation of the enhancement of phosphorus segregation should be given in terms of the model of site competition of carbon and phosphorus, since the concentration of dissolved carbon and segregated carbon at grain boundaries were found to be decreased by the presence of manganese as shown in Fig.6 and Fig.7.

Carbon segregation

Apart from the effect of site competition, the carbon segregation is of great interest because carbon can strength the grain boundary inherently /9/. To clarify the segregation behavior of carbon, the present results can be compared with a recent AP-FIM study of carbon segregation to the martensitic lath boundary /13/. In the lath boundary of the specimen with 1.5 wt.\% $\mathrm{Mn}$ (specimen: $F$, aging: $2 \mathrm{~h}-600^{\circ} \mathrm{C}$ ) phosphorus and manganese were found to be segregited in fairly large amount (ca.5 at.\%) but carbon was segregated in much smaller amount. On the other hand the concentration of segregated carbon was found to be of the order of 20 at\% in the case of Mo steels without manganese. The effect of manganese on carbon segregation to the grain boundary studied by AES is qualitatively in good agreement with that to the lath boundary studied by AP-FIM.

\section{Manganese segregation}

As far as the effect of manganese segregation on the grain boundary embrittlement is concerned, the present results can be compared with the recent

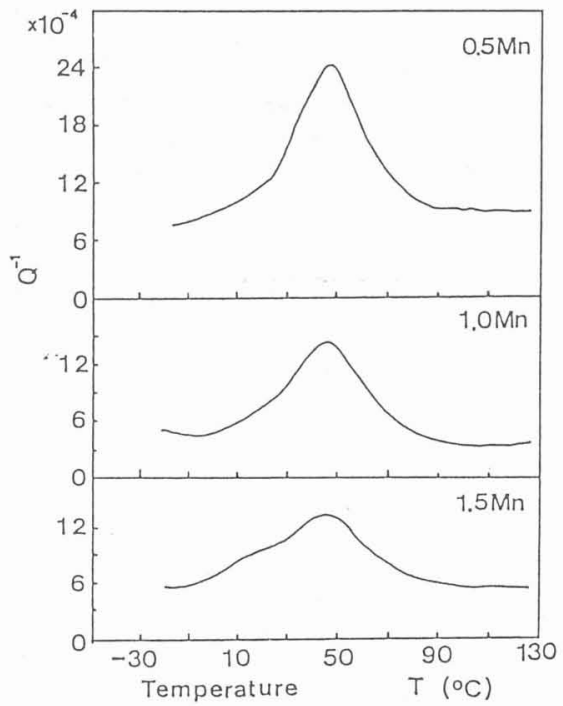

Fig.7 Variation of carbon snnoek peak height in low alloy steels containing $0.5,1.0$ and $1.5 \% \mathrm{Mn}$ (sample: G, H and I aged for 200 h at $\left.600^{\circ} \mathrm{C}\right)$

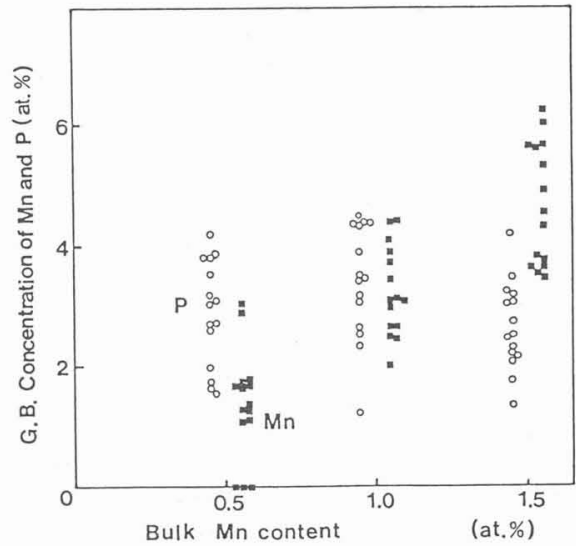

Fig.8 Effect of bulk concentration of $\mathrm{Mn}$ on grain boundary concentration of $\mathrm{P}$ and $\mathrm{Mn}$ in $\mathrm{Fe}-\mathrm{Mn}-\mathrm{P}$ alloys aged for 1 hour at $700^{\circ} \mathrm{C}$ ( $\mathrm{P}$ content:0.02 wt.\%) 
study using $\mathrm{Fe}-\mathrm{Mn}-\mathrm{P}$ alloys containing 20, 50 and 85 wt.ppm C (Fig.9). The figure showed that the manganese has no effect on the percentage of intergranular fracture of the specimens fractured in a standard impact test at $-196^{\circ} \mathrm{C}$. This indicates that addition of manganese has no significant effect on the intergranular fracture in the specimens with carbon content of less than its solubility limit.

Based on these facts, it appears that the amount of segregated carbon is a dominant factor governing the degree of the embrittlement in low alloy steels with different manganese content.

\section{V-CONCLUSIONS}

The effect of manganese on the grain boundary embrittlement in low alloy steels was studied, using AES. The main results are:

1. Phosphorus segregation increases slightly with increasing bulk mangariese content up to $1.5 \mathrm{wt. \%}$.

2. Manganese is segregated at the grain boundary.

3. The amount of segregated carbon decreases as the bulk manganese content increases.

The embrittling effect of manganese can be explained by the decrease of the concentration of segregated carbon which strengthens grain boundaries.

\section{REFERENCES}

/1/J.Q.Clayton and J.F.Knott:Metal Sci.,16(1982)145

/2/J.F.Smith, J.H.Reynolds and H.N.Southworth:Metal Science, 15(1982) 431

/3/D.Y.Lee, E.V.Barrera, J.P.Stark and H.I.Marcus:Metall.Trans.15A(1984) 1415

/4/C.L.Briant:Scripta Met.15(1981)1013

/5/H.Erhart and M.Paju:Metal Science,17(1983)171

/6/L.E.Davis, N.C.MeDonald, P.W.Palmberg, G.E.Riach and R.E.Weber:Handbook of Auger Electron Spectroscopy, Physical Electronics. Industries(1976)

$/ 7 /$ K.Tatsumi, N.Okumura and S.Funaki:Suppl.Trans.Japan Inst.Metals(1986) 427

/8/C.L.Briant:Acta.metall., 31(1983)257

19/S.Suzuki, M.Obata, K.Abiko and H.Kimura:Scripta Met.17(1983)1325

/10/C.L.Briant and S.K.Banerji:Met.Trans.13A(1982)827

/11/Der-Hung Huang and G.Tomas:Met.Trans.2(1971) 1587

/12/Weng Yu-qing and C.J.McMahon, Jr.:Suppl.Trans.Japan Inst.Metals(1986) 579

/13/K.Tatsumi, R.Uemori, M.Yamamoto, N.Okumura and M.Tanino:J.Iron and Steel Institute of Japan 73(1987) in press 